\title{
THE EU INTERNAL MARKET AND NATIONAL TRADITION AND CULTURE: ANY ROOM FOR MARKET DECENTRALISATION?
}

\begin{abstract}
Janja Hojnik*
Summary: The paper explores the issue of national culture and tradition within the framework of the EU internal market. It presents a discussion on the legitimacy of European economic integration. The author takes as a starting point the motto 'Europe united in diversity' and discusses the meaning of diversity in the field of the internal market. The paper emphasises the importance of institutional analysis in EU market law and analyses constitutional relations between national and supranational levels of government in the internal market field. Legal practice in the internal market (the case law of the EU Court and legislation) shows a pro-centralistic orientation, within which several aspects of national culture and tradition have been sacrificed. However, the Court and EU legislator have not openly discussed different institutional alternatives; instead they have mostly referred to the benefits of the established rules for the majority of European citizens. In doing so, they have eroded national regulatory autonomy in the market field and many important aspects of national tradition and culture have been sacrificed for reasons of pursuing an ideal internal market, eg national food and drink laws (Italian pasta rules and German beer production), rules on working days (Sunday trading) and hours (e.g. Spanish siesta), the metrical system, etc. The European process of market law uniformity, however, is contestable when assessed in the light of democratic legitimacy. In this regard, the paper analyses the effects of the principle of subsidiarity on institutional analysis in the field of the EU internal market.
\end{abstract}

\section{Introduction: diverse interests and uniform rules}

In terms of its Member States' economic development and natural features, as well as the traditional cultures and values of their different political systems, the EU is internally very diverse. In this respect, the EU's enlargement from fifteen to twenty-seven Member States with a total population of almost 500 million does not just mean more of the same, but a further increase in diversity. Enlargement brought twelve

\footnotetext{
* Assistant Professor, Faculty of Law, University of Maribor, Mladinska 9, 2000 Maribor, Slovenia, e-mail: janja.hojnik@uni-mb.si.
} 
new languages and plenty of new political alliances among the states. It brought twelve relatively unknown national cultures (to the old Member States) and numerous minority languages and cultures that have more than doubled the number of minorities in the EU. ${ }^{1}$

In such a diverse system, the appropriateness of uniform rules for all is contentious. ${ }^{2}$ The appropriateness of legal rules is measured by the standard of living in a specific area, considering that inhabitants of wealthier regions are prepared to pay more for health, environmental protection and public security than inhabitants of poorer areas. In addition, individuals' tastes differ from one region to another, thereby influencing the appropriateness of legal provisions. The majority's attitude towards gambling or pornographic material depends upon the religious and cultural background of the inhabitants in a certain area. Direct geographical factors can also sometimes influence the content of law, eg some time ago, the Dutch government defended a Royal Decree before the Court that provided for a certain percentage of vitamin D in margarine by saying that people acquire vitamins from sunshine and that in countries which receive less sunshine, such as the Netherlands, individuals need to increase their vitamin $\mathrm{D}$ levels by consuming it through their food and that it was thus legitimate that the legislature address the vitamin shortage issue by means of law. ${ }^{3}$ This means that the advantages and disadvantages of legal rules for inhabitants of certain regions vary and so does the optimum content of legal provisions. ${ }^{4}$ Toggenburg therefore metaphorically says that diversity is a wild and chameleon-like animal with thousands of heads that can hardly be kept in a cage of a single legal principle. ${ }^{5}$

The uniformity of legal rules, however, is not only practically problematic, but also undesirable from the point of view of democratic legitimacy, which is a precondition for any democratic society. The cultural diversity of the EU Member States and distinct national sentiments prevent the EU from legitimately adopting uniform rules to deal with the

\footnotetext{
1 For a discussion on the impact of the last two enlargements upon EU law, see M Jozon, 'The Enlarged EU and Mandatory Requirements' (2005) 11(5) European Law Journal 549.

2 JR Macey, 'Federal Deference to Local Regulators and the Economic Theory of Regulation: Toward a Public-Choice Explanation of Federalism' (1990) 76 Virginia Law Review 265, 281; I Markovits, 'Reconcilable Differences' (1999) 47 American Journal of Comparative Law 189.

3 Case C-273/94 Commission v Netherlands [1996] ECR I-31.

4 JL Goldsmith and AO Sykes, 'The Internet and the Dormant Commerce Clause' (2001) 101 Yale Law Journal 785, 790.

5 GN Toggenburg, 'Unification via Diversification - What does it Mean to be "United in Diversity"?' (2004) EUMAP online journal <http://www.eumap.org/journal/features/2004/ bigday/diversity> accessed 1 December 2006.
} 
diverse problems of its Member States. ${ }^{6}$ This is true also for the internal market field. The internal market has in principle been established, but nevertheless remains a subject of numerous discussions. The reason for this is that various EU legal documents call for an increase in its effectiveness. ${ }^{7}$ While discussing the effectiveness of the internal market, the issue of the legitimacy of EU market rules must be considered as well. The latter should present the essential aspect of any analysis of market success, given that legitimacy gives a broader quality to market rules, ensuring a more consistent application, while on the other hand illegitimate market rules, irrespective of how ideal a market they establish in theory, can hardly be enforceable in practice and therefore cannot be regarded as effective in democratic legal systems.

This paper argues that the principle of subsidiarity as an answer to a democratic legitimacy deficit in the EU has a vital role to play when choosing between various institutional alternatives (centralist and decentralist concepts) and should also have an important impact upon the division of powers between the EU institutions and its Member States in the field of the internal market, especially in terms of preserving national traditions and cultures. ${ }^{8}$

\section{Institutional alternatives in the EU internal market}

\subsection{Centralist and decentralist market approaches}

The ongoing economic crisis proves that the market cannot self-regulate. Therefore, economic autonomy cannot be an option for the future. Should we agree that legal intervention in the market is necessary, the next step is to determine who the competent authority is for such intervention. The main constitutional law alternatives for regulating the EU market are the institutions of the Member States (as the historically primary regulators of their respective national markets) and the EU institutions (as relatively new regulators of the common/internal market, which

${ }^{6}$ Central authorities may certainly adopt rules that change from one territory to another. However, this is not their usual modus operandi (at least not in the EU). For the new Member States that have only recently rebuilt their sovereignty, it is even more important that they do not lose their identity within the EU and that they can defend their special national interests.

7 See Commission, 'Europe 2020, A strategy for smart, sustainable and inclusive growth' COM (2010) 2020 final; M Monti, 'A New Strategy for the Single Market: At the Service of Europe's Economy and Society' (2010) Report to the President of the European Commission <http://ec.europa.eu/bepa/pdf/monti_report_final_10_05_2010_en.pdf> accessed 11 September 2011; Commission, 'Single Market Act: twelve levers to boost growth and strengthen confidence "Working together to create new growth" COM(2011) 206 final.

8 For more on this, see LFM Besselink, 'Respecting Constitutional Identity in the EU' (2012) CML Rev 671-693. 
in the past fifty years have acquired the central role in this field). In this regard, the question of the relationship between the two levels of the institutions arises, thereby reflecting an antagonism between demands for a greater diversity on the one hand and a broad uniformity of internal market rules on the other. What an analysis of the institutional alternatives of the EU internal market requires is therefore an assessment of the constitutional legal status of the EU economic order as reflected in the legislation and case law in this core EU legal field.

The basic constitutional conflict in the field of the internal market is a conflict between centralism and decentralism. ${ }^{9}$ These are two fundamental approaches of legal theory to the issue of the constitutional legal nature of the EU internal market. Centralism in this context refers to a system in which the EU regulates most economic activities and where the competences of the Member States are generally excluded (a laissez-faire approach). Decentralism, on the other hand, refers to a system, in which most aspects of economic regulation are left to the Member States (a laissez-régler approach). However, the latter are bound by the principles of free movement of goods, services, people and capital. Decentralism, as understood in this paper, therefore refers to a limited decentralism, as it is based on the limited autonomy of the Member States. The first approach defends a wide-ranging transformation of internal market rules into a free-trade commitment where the market rules form the basis for economic liberalism, an open market and free competition. The second approach, on the other hand, considers that the only purpose of the rules on free movement is to limit state protectionism and discrimination.

Although each of these approaches has its advantages and disadvantages, a decentralist approach gives preference to democratic values, whereas a centralist one favours economic effectiveness. Democracy and economic effectiveness are thus contradictory values. Should one only choose economic efficiency as a factor of choice between the institutional alternatives, then the choice will certainly be oriented towards centralism. On the other hand, if the main goal is the preservation of national sovereignty, a decentralist approach will be given preference. In case neither of the goals is to be disregarded, an appropriate balance between centralism and decentralism must be established when considering various institutional alternatives in the market.

Ever since the Treaty of Rome came into effect, economic arguments have prevailed in the internal market establishment process: market liberalisation to increase competitiveness and to achieve economy of scales comparable to the production of companies from Europe's competitive

\footnotetext{
9 J Snell, Goods and Services in EC Law: A Study of the Relationship between the Freedoms (OUP 2002) 32.
} 
markets. In this process, however, it is often forgotten that market rules spread to very diverse legal fields and that such centralistic regulation is not always the most justifiable, and may be in opposition to the interests of diversity. In the EU, diversity is an increasingly obvious fact. It has been declared the most notable characteristic of integration, ${ }^{10}$ and at the same time has become a legal concept. Affirming the competences of decentralist authorities in certain legal fields may in this respect achieve greater democratic legitimacy for the adopted rules, as it preserves the diversity of national rules.

\subsection{Choice of institutional alternatives in the field of the EU internal market in practice}

Although the Court and EU legislators in no respect advocate complete deregulation, the judgments of the Court and EU secondary legislation in the market field considerably limit Member States' prospects to adopt or preserve diverse market rules. This, however, is disputable considering the undoubted orientation of citizens towards their states as primary forums for democratic activities. Deriving from the widely adopted thesis that a true European demos does not exist, uniform market rules, which are built on the idea that European citizens have the same needs and a unified perspective of the world, raise questions regarding the democratic legitimacy of such rules.

In order to increase the legitimacy of EU market rules, the Court has transformed the Member States' obligations, imposed by the Treaties, into individual rights of EU citizens which are enforceable before the national courts. The Court has justified most of its internal market judgments on the basis of the economic constitution theory that considers the freedom of individuals as the ultima ratio of market intervention by central institutions. Consequently, the Court's decisions (at least at first sight) do not solve the conflicts between the EU and its Member States, but protect the rights of individuals from these states - in some cases against their home states. Since the Court relies on the assumed will of the majority of citizens when justifying its decisions, in theory it is a majoritarian approach. Even though the Court has not openly discussed the importance of market rule interpretations for the constitutional division of competence, and even though the Court has avoided interference in political debates by wrapping its decisions in the language of individu-

\footnotetext{
10 The EU motto that first came into use in 2000 is 'Europe - united in diversity' and is explained as signifying 'how Europeans have come together, in the form of the EU, to work for peace and prosperity, while at the same time being enriched by the continent's many different cultures, traditions and languages' European Union < http://europa.eu/abouteu/basic-information/symbols/motto/index_en.htm> accessed 27 July 2011.
} 
als' fundamental freedoms, its rulings in this field nevertheless include decisions on the division of competences among Member States and EU institutions. Various interpretations of the internal market rules necessarily lead to the determination of the institutions that are responsible for market regulation. ${ }^{11}$ When increasing and limiting the scope of legal principles in the market field, the Court actually in a discretionary manner determines which competences the Member States should have and in which fields they may not intervene, as they are reserved for the EU legislators. Therefore, when the Court decides that a Member State's measure is a prima facie hindrance to a market freedom, it thereby confers the regulatory competence to the EU and thus supports the centralistic approach to the internal market. ${ }^{12}$ The wider the market freedoms, the more centralised the EU system is.

To a certain degree, constitutional discourse is more transparent in relation to EU legislation, where unanimity and the majority principle of decision-making have openly presented a discourse on the autonomy of the individual Member States. Therefore, even though the majority voting rule enables circumvention of a single Member State's interests, and EU legislation per se limits national regulatory autonomy, centralism is not a necessary result of the EU legislator. In the light of this, various approaches to harmonisation at the EU level have been developed and recently new forms of regulation have become increasingly important. These emphasise not only the role of states in the legislative procedure but also that of civil society in general, which should through co-ordination at different levels lead to more legitimate rules. Within EU legislation, the tension between centralism and decentralism is evident from the discussions on negative and positive integration. According to the former, internal market rules should only require the Member States to abandon interference in interstate trade. Member States are still the main formulator of market policy in this respect, but under the condition that they do not discriminate against goods, people, services and capital from other Member States. On the other hand, positive integration requires the active participation of Member States in terms of unifying domestic legislation with that which has been adopted at the supranational level. In this situation, the market decision-maker is the supranational legislator, which adopts harmonising legislation, whereas the Member

${ }_{11}$ M Maduro, We The Court, The European Court of Justice and the European Economic Constitution: A Critical Reading of Article 30 of the EC Treaty (Hart Publishing 1998) 103104. For a discussion on the Court of Justice's role in the process of legal integration, see KA Armstrong 'Legal Integration: Theorizing the Legal Dimension of European Integration' (1998) 36(2) Journal of Common Market Studies 155.

12 In this regard, Snell emphasises that EU legislation is not conditioned upon a barrier on the side of the Member States. The existence of a barrier is a sufficient, but not an essential condition for harmonisation. Snell (n 9) 33 n 10. 
States' role is limited to its application. In this respect, it must be emphasised, however, that the delimitation between negative and positive integration and their transformation into a centralist or decentralist approach to the internal market is of a theoretical nature only. As proven by the Court's case law, negative integration may also lead to considerable loss of national autonomy. Critics therefore warn that enforcement of TFEU provisions on fundamental freedoms has led to deregulation across the EU and the lowering of standards in the fields that are closely related to the internal market. ${ }^{13}$ On the other hand, harmonisation as an agent of positive integration does not necessarily exclude Member States' competences in the market field.

\section{Economic liberalisation versus national tradition and culture}

\subsection{General remarks}

The main minority values that have been impaired by the Court's orientation towards the majority in the market, which has led to the most evident lack of democratic legitimacy, are those of national tradition and culture. ${ }^{14}$ Market rules directly reflect national tradition, ie the way people live. This is true for national food laws determining certain ingredients or additives, for national family law that determines the ways families live, and also trade law, which determines the opening hours of shops and prohibits the selling of certain products (eg alcoholic drinks or erotic magazines). Given that the Treaty of Rome was of an economic nature, it was not expected to have a significant effect in a broad sense upon the culture which determines the specific nature of individual Member States and the daily lives of their inhabitants. In reality, however, the Court has interpreted TFEU provisions in such a far-reaching way that market principles have begun to interfere in various aspects of people's lives, not just in national trade legislation (irrespective of how broadly one may understand the term 'trade'). It goes without saying that not all traditional rules are positive, and EU law removing some of them (eg regarding cruelty to animals) has been a welcome move. However,

\footnotetext{
13 A McGee and S Weatherill, 'The Evolution of the Single Market: Harmonisation or Liberalisation?' (1990) 53 MLR 578, 581.

14 While many commentators have expressed their concern about the deregulatory potential of the Court's decisions, Weatherill, on the other hand, finds that 'European market integration confronts the dead wood of centuries of regulatory tradition in all the Member States ... [R]egulatory renovation and a bonfire of red-tape on the pyre of Article 34 TFEU constitutes the anticipated, even necessary, method. ... [T] he European court is frequently asked to deal with the collision between, on the one hand, the making of a market for Europe and, on the other, national rules introduced for once sound reasons that have generations ago lost their purpose.' S Weatherill, 'Pre-emption, Harmonisation and the Distribution of Competence to Regulate the Internal Market', in C Barnard and J Scott (eds), The Law of the Single European Market: Unpacking the Premises (Hart Publishing 2002) 41, 49.
} 
the Court's case law in particular has on many occasions interfered in national rules that are a source of pride. By doing this, it has triggered citizens' concern and a fear of the erosion of their traditional values.

In this regard, it is arguable whether national tradition and culture as components of democratic legitimacy can compete with economic liberalisation, considering that tradition and culture are related to the peoples of Europe and are as such of a minority nature, whereas liberalisation has a supranational dimension. We believe that tradition and culture should be considered as values of significant importance in comparison to economic effectiveness, as they are inherent to every Member State and serve as a basis for the identity-building of their citizens. For these reasons, Member States have an interest in establishing an appropriate balance between economic liberalisation on the one hand and national tradition and culture on the other, as they all contribute to an appropriate quality of life. The appropriate balance does not refer to a situation where national tradition would always override free market interests. Nor does it refer to the opposite situation, but various solutions in between that are established in practice, not as a consequence of one institution's decision, but discussion among institutions and entities that represent various interests. Protection of tradition and culture is nowadays an unimportant political concept. Nevertheless, it contradicts all-encompassing harmonisation, not just at the EU level, but also at the Member State level. ${ }^{15}$ The following chapter discusses examples of establishing such a balance in the past. In many of them, the Court gave little or no importance to national tradition and culture.

\subsection{Erosion of national tradition and culture in the EU Court's case law}

\subsubsection{National food laws}

One of the main areas where EU Member States substantially differ and which presents a source of their recognisability and national pride is their culinary tradition, determined by the local climate, and social and cultural factors. This fact has also led to a considerable amount of case law of the EU Court in the field of food and beverages. The interlacing of EU market law and national tradition concerning alcoholic drinks can be found in early tax case law. In the most famous case in this

15 The position of the Assembly of the Council of Europe is that the identification of national minorities and assurance of effective guarantees for their rights at the international level present the main way to remove ethnic conflicts and to establish peace in Europe. See eg C of E, Resolution of the Parliamentary Assembly of the Council of Europe 1335 (2003) of 19 June 2001. 
field, Great Britain was taxing wine more heavily than beer. ${ }^{16}$ We may (dis)agree over the question of whether beer and wine are to be regarded as substitutes. However, the Commission alleged that Article 110 TFEU (former Article $90 \mathrm{EC}$ ) was being infringed, as wine was disproportionately more heavily taxed than beer, considering that Britain had practically no domestic wine production. The British government, on the other hand, relied on traditional drinking patterns in Great Britain, claiming that beer was a popular beverage, whereas wine was a luxury product, thereby denying the substitutability of the two drinks. The Court did not accept this argument.

The majority of traditional national rules in the field of food and beverages, however, are not to be found in the taxation field, but in national laws regulating food ingredients and their presentation which follow health and consumer protection goals. One of the first cases in which a Member State relied on national tradition was Reinheitsgebot, ${ }^{17}$ where the German government claimed that a national tradition was the reason for hindering trade. This tradition involved the prohibition of selling bier that contained any additives, and permitting only beer that was produced by the traditional (pure) German method. The German government claimed before the Court that German consumers associated the designation bier with the beverage as prescribed in Biersteuergesetz, ie pure beer, and any other ingredients in the beer would be misleading to consumers. The German government quoted the reasoning of the Council when justifying directives to harmonise standards for other products, in the sense that such a standard was necessary because practically every traditional drink could be produced artificially now. ${ }^{18}$ The Court did not accept this argument, holding that:

Consumers' conceptions which vary from one Member State to the other are also likely to evolve in the course of time within a Member State. The establishment of the common market is, it should be added, one of the factors that may play a major contributory role in that development. ${ }^{19}$

It follows that national traditions may not be static and also that EU Member States should not regulate them in such a way that they become so, as this would harm the goals of the internal market. After this judgement, the media was full of protests by German beer producers and consumers claiming that 'the Commission had dared to issue against

16 Case 170/78 Commission v United Kingdom [1983] ECR 2265.

17 Case 178/84 Commission v Germany [1987] ECR 1227.

18 See E Steyger, National Traditions and European Community Law: Margarine and Marriage (Dartmouth Publishing 1997) 34.

19 Commission v Germany (n 17) para 32. 
the superior quality of German beer by attacking before this Court rules on purity dating back to the time of Martin Luther. ${ }^{20}$

Since pasta has a similar significance in terms of national pride in Italy as beer does in Germany, Italians also began to protest when a magistrate from Bolzano referred for preliminary ruling the question of whether traditional Italian pasta rules were in accordance with EU law. In Italy, special durum wheat (grano duro) was used to prepare pasta. Italian law prohibited the marketing of any other kind of wheat. With the support of Advocate General Mancini, ${ }^{21}$ the Italian government maintained that the prohibition was necessary to protect Italian customers from buying and eating low-quality pasta. ${ }^{22}$ The Advocate General explained his opinion by saying that those that do not know Italy and Italian may think that the terms pasta, tipi di pasta and paste mean the same thing, even though this is not true. Relying on an encyclopaedia, he emphasised that pasta in the singular and paste in the plural have different meanings, and that only Italians knew the correct meaning of the words spaghetti, vermicelli, bucatini, maccheroni, rigatoni, fusilli, penne, linguine, orecchiette, malloreddus, etc. ${ }^{23}$ Consequently, considering the importance of pasta for Italians, the Advocate General proposed that the Court confirm the Italian law on durum wheat. However, the Court did not accept the reasoning and concluded that the law presented an unjustifiable measure having an equivalent effect to quantitative restrictions. The Italian market therefore had to open up to pasta made from different wheat. ${ }^{24}$

\subsubsection{Traditional labelling and packaging}

The most important tradition of the EU Member States related to products is the language in which products are labelled. Considering the many languages that exist in the EU, it is a demanding job to label all the products' ingredients correctly when trading across the EU. Consequently, a directive ${ }^{25}$ stipulates that Member States may prohibit

\footnotetext{
20 Case 407/85 Drei Glocken v USL Centro-Sud [1988] ECR 4233 Opinion of AG Mancini.

21 Opinion of AG Mancini (n 20).

22 Pasta made of durum wheat does not stick together after cooking.

23 The Advocate General on the other hand acknowledged that the purpose of Italian legislation was also to encourage the production of hard wheat, which in certain regions of Mezzogiorno is the only successful crop.

24 See Case 90/86 Criminal Proceedings against Zoni [1988] ECR 4285. Giorgio Zoni was prosecuted for importing wheat from Germany which was a mixture of ordinary and durum wheat.

25 Council Directive 79/112/EEC of 18 December 1978 on the approximation of the laws of the Member States relating to the labelling, presentation and advertising of foodstuffs for sale to the ultimate consumer, OJ 1979 L33/1.
} 
the marketing of products that do not contain information on the label which is in a 'language easy to understand for the customer'. ${ }^{26}$ Some Member States have interpreted this provision as meaning 'in the official language'. Belgium in this respect stipulated that the language used on the labels of food should be that of the area in which the food is offered for sale. ${ }^{27}$ Belgium has a rich history of language disputes and three official languages at the present time, therefore food producers had to provide for three different labels to be able to market their products in their own country. The Court did not accept the interpretation of the Belgian government and ruled that the directive does not allow Member States to require labels in their own language if another language could be considered understandable. The judgment was severely criticised, not only because the protection of consumers might be jeopardised, but also because of its negative meaning for the protection of native languages. ${ }^{28}$

A slightly different, but nationally no less sensitive question is Member States' competence to reserve certain designations of origin for products coming from a certain region and consequently to allow them to refuse to import products of other Member States for the reason that the latter bear a similar name. The national rules concerning designations of origin derive from the national pride of typical national or regional specialties that are usually produced according to traditional methods. ${ }^{29}$ The products derive their special status from their names and origins. Nevertheless, many of these products are imitated by producers in other Member States. The question if and what kind of names may be reserved by Member States has led to numerous judgments of the Court. The latter in general has ruled that names can be protected only if the qualities and characteristics of the product concerned actually depend on its geographic origins. ${ }^{30}$ In this regard, a lot of attention was given to the feta cheese saga. Disputes over the use of the name feta began before the Court over two decades ago, ${ }^{31}$ when a question was referred to the Court whether this name could be used for certain cheeses made from cow's milk. ${ }^{32}$ Originally, the name feta was used for Greek cheese made from sheep or goat's milk and produced according to a traditional produc-

\footnotetext{
26 Council Directive 79/112/EEC (n 25) Article 14.

27 Case C-369/89 Piagème v Peeters [1991] ECR I-2971. The case later came before the Court again: Case C-85/94 Piagème v Peeters II [1995] ECR I-2955.

28 Steyger (n 18) 40. See also Case 298/87 Smanor SA [1988] ECR 4489.

29 Steyger (n 18) 42.

30 Case 12/74 Commission v Germany (Sekt and Weinbrand) [1975] ECR 181.

31 In Greece, a national court had already decided in 1987 that feta may only be used for Greek cheese.

32 Case C- 317/95 Canadene Cheese Trading AMBA cs v Ypourgou Emporiou [1997] ECR I-4681.
} 
tion process. Over the years, Danish, German and other imitations of this cheese from cow's milk emerged and were good enough to convince Greeks to import it. The question for the Court was whether the name feta could be reserved for the traditional cheese made of sheep or goat's milk and whether the Greek authorities could stipulate that the imported cheese carry a different name. The opinion of the Advocate General was that national legislation that prohibited the sale of cheese under the name feta which was legitimately produced and marketed under this name in another Member State was a measure having equivalent effect to quantitative restrictions, which could not be justified. ${ }^{33}$ However, after additional research and a long series of disputes the Court finally ruled that numerous factors show that the characteristics of feta are an essential result of a defined geographical area. In this regard, the Greek government submitted a specification of numerous natural and human factors that give feta its specific characteristics, such as the quantity of sun, fluctuations in temperature, seasonal migration of animals, increased grazing and vegetation. These specifics led the Court to the conclusion that the word feta does not have a generic character. ${ }^{34}$ Its decision was a source of widespread approval among Greeks and serves as an example of where the Court considered a minority Greek interest over the majority interest of other states where this famous cheese was imitated.

In addition, decisions on what should be regulated and what not follow from national traditions. Some aspects of this tradition are religiously inspired, others stem from morality and culture. These rules in general fall within the competence of the Member States. However, they cannot avoid the Court's interference. The latter has often considered cases regarding the closing times of shops, and questions regarding media, advertising, gambling, etc.

\subsubsection{Closing times of shops}

National rules on closing hours for shops generally aim to protect workers. Additionally, in some Member States legislation on when shops should be closed have a more traditional background. The traditional Sunday closing in several Member States is closely related to the Christian religion. Should this legislation only protect workers, the shops could easily be closed any other day of the week. Despite Europe's major-

\footnotetext{
33 Case C-317/95 Canadane Cheese Trading v Greece [1997] ECR I-4681 Opinion of AG Ruiz-Jarabo Colomer. Case removed from the register.

34 Joined Cases C-465/02 and C-466/02 Germany and Denmark $v$ Commission [2005] ECR I-9115. For comments, see R Knaak, 'Gemeinschaftsweiter Schutz der Bezeichnung „Feta“ für Erzeugnisse aus Griechenland' (2006), Zeitschrift für das gesamte Lebensmittelrecht 59; J Reed, 'Feta: A Cheese or a Fudge? Federal Republic of Germany v Commission' (2006) European Intellectual Property Review 535.
} 
ity attachment to Christianity, rules in this respect vary between Member States. ${ }^{35}$ These differences have led to numerous attempts to abolish mandatory Sunday closing regulations in several Member States. According to the claimants, these rules infringed upon the free movement of goods, as customers would avoid areas in which shops were closed on Sundays and prefer those where shops were open. The Court held in Torfaen ${ }^{36}$ that Article 34 TFEU covers not only product regulations but also measures regulating market circumstances. The British government invoked historical reasons to explain the English closing of shops on Sundays and the differences between English and Scots law, which permitted the opening of shops on Sundays. In Conforama, ${ }^{37}$ where the French government had to defend its rules on shops closing, the claimant admitted that French law reflected religious considerations which had been influential in 1906, when the law was introduced, but also claimed that the law was out of date and should be replaced by prescribing a weekly rest period in general instead of confining it to Sundays. Although the Court decided that these rules prima facie hindered the free movement of goods, it nevertheless dismissed the claimant's arguments by holding that these rules reflected certain choices particular to national or regional socio-cultural characteristics which were for the Member States to make.

Even though the final decision of the Court is democratically legitimate, the same does not hold for its broad interpretation of Article 34 TFEU, which included rules that are completely non-discriminatory and have only a very distant effect on cross-border trade, or the fact that the Court reserved for itself the competence to decide on the legitimacy and proportionality of national measures. The argument in fact shows that such rules do not hinder cross-border trade at all, as the domestic and imported goods within a Member State are in a completely equal position. In this regard, it may be emphasised that in the USA rules on rest days are within the states' competence and have never been challenged as a hindrance to trade among states in contrast to the commercial clause. ${ }^{38}$ The challenged rules have been considered by the US Supreme

\footnotetext{
35 At this point, it is not clear why shops are closed on Sundays in England, Germany and the Netherlands, which are predominantly Protestant, whereas they are mostly open in Belgium and several other Catholic states.

36 Case 145/88 Torfaen BC v B\&Q [1989] ECR 3851.

37 Case C-312/89 Conforama [1991] ECR I-991.

38 Maduro (n 11) 92. Prohibition of Sunday trading was not considered as a barrier to the internal market even in Great Britain, where England enacted its well-known Sunday Trading Act but Scotland does not have similar rules on Sunday trading. This difference was not considered as a barrier to free trade between England and Scotland that would need justification. See T Burke and JR Shackleton, 'Sunday: The Issues in Sunday Trading', Adam Smith Institute (1989) 22 <http://www.adamsmith.org/sites/default/files/images/ uploads/publications/Sunday,_Sunday.pdf> accessed 28 September 2012.
} 
Court only from the point of view of freedom of religion, but also in this respect the Supreme Court did not challenge the states' competence in the field. ${ }^{39}$

Numerous national traditions die out for reasons of globalisation without the EU's institutions expressly requiring it. For example, Spanish accession to the European Economic Area required the adjustment of their inhabitants to a shorter lunch time as is usual in other Member States. Consequently, their traditional working day with three hours lunch time for siesta (a meal and a nap) quickly began to disappear. Thus, in January 2006 the Spanish government adopted a rule that all federal offices officially have only a 45 -minute lunch break. The private sector followed this practice. This required numerous changes, from the working time of restaurants to the main TV news. ${ }^{40}$ Globalisation therefore eliminates traditions, even though this means a "push back from a cultural standpoint. ${ }^{41}$ However, this is only slowly coming into practice given the deep roots in Spanish workers' mentality.

\subsubsection{National heritage}

Similar to the aforementioned legal fields, EU law has also surprised Member States in the field of national heritage. In the sixties, Italy introduced a law which in some cases prohibited the export of cultural heritage and in others required the exporter to pay a tax calculated on the basis of the market value of the objects concerned. Italy claimed before the Court that items of artistic, historical or ethnographic interest were not goods in the ordinary sense and were therefore not subject to the Treaty provisions on the free movement of goods. ${ }^{42}$ The Court dismissed this argument by ruling that 'goods ... must be understood [as] products which can be valued in money and which are capable, as such, of forming the subject of [a] commercial transaction. ${ }^{43}$ As a consequence, the protection of national heritage cannot be achieved by levying charges on protected objects, as they are considered as charges of equivalent effect to customs duties. Nevertheless, national heritage can be protected through a prohibition on export, as justified by a specific reason pro-

\footnotetext{
39 Braunfeld $v$ Brown 366 US 599 (1961).

40 JW Anderson and J Green, 'Shaking Spain out of its Siesta, Law Seeks to Put Nation on Same Schedule as Rest of EU' Washington Post (23 April 2006) <http://www.washingtonpost.com/wp-dyn/content/article/2006/04/22/AR2006042201123.html> accessed 15 September 2011.

41 J Deschenaux, 'Less Time for Lunch: The Siesta in Spain is Disappearing under the Pressures of International Business and Big City Communing' (HR Magazine 2008).

42 Case 7/68 Commission v Italy [1968] ECR 423.

43 Commission v Italy (n 42) para 428.
} 
vided in Article 36 TFEU. ${ }^{44}$ Hence, Member States may prevent tourists or other buyers from exporting national heritage, but it is not allowed to make money out of such exports.

A kind of reverse case, however, occurred in Ireland, which encouraged tourists to buy traditional domestic products as souvenirs. Irish law required foreign products of typical Irish souvenirs to be stamped with an indication of origin. The purpose of the rule was to protect the domestic souvenir industry and tourists who might feel cheated upon discovering that their valued Irish souvenir was actually made in Denmark or even Taiwan. ${ }^{45}$ The Court had no mercy with these aims and considered the rule directly discriminatory, so that reliance on the rule of reason was not even possible. Article 36 TFEU was not applicable to the facts of the case. ${ }^{46}$ The decision is disputable from the standpoint of consumer protection, while the Court's definition of a souvenir (for which the place of purchase, not the place of production prevails) is not legitimate. ${ }^{47}$

\subsubsection{Media law and the film industry}

Strong emotions rooted in traditional attitudes in the Member States were also raised in relation to the Court's case law in the area of media law. Audiovisual media have a long tradition of state intervention in Europe. Consequently, in several Member States the commercialisation of television is still regarded as harmful to the people, national culture and contrary to general state interests. ${ }^{48}$ Despite its endeavours to encourage competition in as many areas as possible, EU law does not prohibit public television as such. Since broadcasting may be seen as a public service, Member States fully retain the power to reserve the right to broadcast for the government or to prohibit certain pornographic or vio-

44 Because of Council Directive 93/7/EEC of 15 March 1993 on the return of cultural objects unlawfully removed from the territory of a Member State [1993] OJ 1993 L74/74, Article $36 \mathrm{TFEU}$ is no longer applicable in this field.

45 Steyger (n 18) 71.

46 Case 113/80 Commission v Ireland [1981] ECR 1625.

47 Protection of national heritage was also at issue in three cases concerning tourist guides: Case C-145/89 Commission v France [1991] ECR I-659; Case C-180/89 Commission v Italy [1991] ECR I-709; Case C-198/89 Commission v Greece [1991] ECR I-727.

48 Steyger (n 18) 73. Steyger emphasises that the reasons for certain states prohibiting commercial television in favour of the preservation of state television has not always followed from a genuine concern for the well-being of the people watching. As long as broadcasting is kept in the hands of the government, that same government is able to control the issues broadcast. State television may in circumstances where the freedom of press is not guaranteed offer the government the opportunity to censor broadcasts. 
lent programmes or commercials. ${ }^{49}$ Given that the application of Article 56 TFEU, which guarantees free movement of services, presupposes a cross-border element, internal domestic broadcasting did not interfere with Community law. This changed, however, as new technology facilitated cross-border broadcasting, which was quickly embraced by advertising agencies. Consequently, in the Flemish Cable Decree case, ${ }^{50}$ which prohibited broadcasting from bodies from other Member States, the Belgian government invoked the purpose of cultural policy, ie preservation of pluralism of the press, which profited from the advertising revenues from national companies, and also the preservation of national artistic heritage. The Court held that the decree was purely protectionist and thus unjustifiable.

\subsubsection{Morality and family values}

At the time of the adoption of the Treaty of Rome, probably nobody expected that EU law might influence national attitudes towards morality, sex and family values, especially considering that at that time it was not generally acceptable for individuals to rely directly on Treaty provisions before the national courts to invoke their rights. Recognition of this right together with changes in relation to sex and the family gradually led to the considerable impact of EU law on these values over the decades.

In its case law, the Court held that the morally disputable nature of certain goods or services does not exclude the application of the rules on the internal market. Even in the field of free movement of goods, where the TFEU expressly recognises a public morality derogation, the Court ruled in Conegate ${ }^{51}$ that reliance on public morality is not permitted in each case, especially not when the goods are legally produced and marketed in the home state. ${ }^{52}$ In the field of services, the Court also classified indecent services under the TFEU. The Court does not substitute a moral decision of the legislator of the state where a specific activity is legitimate. Consequently, in the Grogan case $^{53}$ the Court decided that

\footnotetext{
49 See Article 9 of Directive 2010/13/EU of the European Parliament and of the Council on the coordination of certain provisions laid down by law, regulation or administrative action in Member States concerning the provision of audiovisual media services (Audiovisual Media Services Directive) OJ 2010 L95/1, which provides certain specific requirements for such programmes.

50 Case C-211/91 Commission v Belgium [1992] ECR I-6757.

51 Case 121/85 Conegate Ltd $v$ Customs and Excise Commissioners [1986] ECR 1007.

52 In Conegate, reference to Article 36 TFEU was made in relation to confiscation of a number of inflatable dolls and certain other objects imported from Germany for reasons of their indecency.

53 Case C-159/90 The Society for the Protection of Unborn Children Ireland Ltd $v$ Grogan [1991] ECR I-4685.
} 
termination of pregnancy, which is legally performed in several Member States, is a service as defined in the TFEU. In addition, in Schindler ${ }^{54}$ the Court ruled that lottery services, even though strictly regulated in several Member States, are not per se prohibited and that in the United Kingdom, which was considered in the case, small-scale lotteries were also allowed. According to the Court, lotteries and other types of gambling are in general considered as harmful. ${ }^{55}$ Nevertheless, they are not prohibited in all Member States and thus fall within the scope of the principle of the free movement of services, ${ }^{56}$ regardless of the fact that the European Council in Edinburgh in 1992 decided that the EU would not regulate games of chance, as it was more appropriate and in line with the subsidiarity principle that Member States alone regulated this field.

The Court adopted the strictest approach towards the national views on morality in the field of free movement of people. The most obvious case in this respect is Adoui en Cornuaille, ${ }^{57}$ which concerned two French prostitutes working in Belgium. When the two women applied for residence permits, the Belgian government expelled them from Belgium for reasons of their personal behaviour, which was considered of doubtful morality, thereby requiring the need to protect public order. In general, policy regarding prostitution was left to the local authorities, and according to the city of Liège the women were considered as delinquents. The first interesting point in the Court's decision refers to the fact that the Court ruled that even prostitution must be considered as work in terms of Article 45 TFEU. Furthermore, the Court held that expulsion for reasons of public policy could only be regarded as justified if the conduct concerned constituted a genuine and sufficiently serious threat to public order. Since the Belgian authorities did nothing to effectively combat prostitution, the behaviour of the French women was not a sufficient reason for expulsion.

In this regard, the Cornwall County Council case ${ }^{58}$ should also be mentioned. It dealt with the effects of sex change on the employment rights of the person concerned. Nearly a year after beginning employment, the person concerned informed the management of an educational institution of his intention to change sex, and began to wear women's

\footnotetext{
54 Case C-275/92 Her Majesty's Customs and Excise v Gerhart Schindler in Jörg Schindler [1994] ECR I-1039. On this case, see L Gormley, 'Reasoning Renounced? The Remarkable Judgment in Keck \& Mithouard' (1994) European Business Law Review 63.

55 Schindler (n 54) paras 31-33. Among the main reasons for this are the high probability of fraud and money laundering as well as the danger of excessive gambling of individuals, which may have long-term social effects (addiction, bad social position of the family, etc.)

56 See also Case C-243/01 Piergiorgio Gambelli and others [2003] ECR I-13031.

57 Joined Cases 115\&116/81 Adoui and Cornuaille v Belgium [1982] ECR 1665.

58 Case C-13/94 P v S \& Cornwall County Council [1996] ECR I-2143.
} 
clothing, which was followed by an operation to obtain the physical attributes of a woman. Before the operations began, the person received three months' notice of termination of employment. In his lawsuit against the employer, he claimed that he was the victim of sex discrimination, while the employer claimed that his/her employment had ended as his/her position had become redundant. The national court ruled that the sex change was in fact the real reason for dismissal. However, such a situation was not considered as discrimination under the English Sex Discrimination Act. The national court was not sure whether it represented discrimination under Directive 76/207/EEC. ${ }^{59}$ The Court interpreted the directive broadly and proclaimed the principle of equality as one of the fundamental principles of EU law, also ruling the dismissal had occurred because of the sex change.

\subsection{Democratic deficit of EU legislation}

Like the Court's case law, EU legislation has also encroached upon various national customs. In this regard, the Directive on units of measurement ${ }^{60}$ should be pointed out. This stipulates that the metre is the official unit for measuring lengths and the kilogramme for measuring weights, and does not mention English units of measurement. Consequently, in 1994 Great Britain adopted new rules to amend the Weights and Measures Act of 1985 so as to prohibit the use of English units of measurement for commercial purposes, except as an ancillary label to decimal units of measurement. This amendment was highly criticised in Great Britain, which might be explained by the opinion Napoleon expressed in relation to the changes of units of measurement proposed by the Paris Academy of Science: 'Nothing is more contrary to the organization of the mind, of the memory, and of the imagination. ... The new system of weights and measures will be a stumbling block for several generations. ... It's just tormenting the people with trivia.'61

What the French emperor refused was imposed on the British by the above-mentioned directive, despite being considered a cultural invasion.

\footnotetext{
59 Repealed by Council Directive 2006/54/EC on the implementation of the principle of equal opportunities and equal treatment of men and women in matters of employment and occupation (recast) [2006] OJ 2006 L204/23.

60 Council Directive 80/181/EEC on the approximation of the laws of the Member States relating to units of measurement and on the repeal of Directive 71/354/EEC [1979] OJ 1980 L39/40, as amended.

61 See P Seymour, 'Drastic Measures: The Metric Assault on American Standards' (Americans for Customary Weight \& Measure 2001) <www.bwmaonline.com/ACWM.htm> accessed 15 April 2011.
} 
This can be deducted from Thoburn and Others, ${ }^{62}$ known as the "metric martyrs', which challenged the legality of the changes before the English courts. Thoburn sold fruit and vegetables using English units of measurement scales, as this was more convenient for his customers, but was prosecuted for this. Before the judgment was published, Thoburn said: 'All I did was sell a pound of bananas to a woman who asked for a pound of bananas - what's wrong with that?'63 The court, however, explained that the judges realised that the parties before them were hardworking citizens, but that '[a]ll the specific rights and obligations which EU law creates are by the European Communities Act incorporated into our domestic law and rank supreme.' Making it clear that no loopholes existed, Lord Justice Laws said, '[t]hat is, anything in our substantive law inconsistent with any of these rights and obligations is abrogated or must be modified to avoid inconsistency.' He added that 'our imperial measures, much loved of many, seem to face extinction'. ${ }^{64}$ Neil Herron, spokesman for the Metric Martyr Defence Fund, said that the case showed that an Act of Parliament could be overruled by a 'mere directive' from 'an entity, a gathering of unelected bureaucrats over which we have no democratic control'. ${ }^{65}$ The critics of the judgment also emphasised that it was difficult to understand why it was hard to have an internal market with two units to measure weight, when the UK internal market had functioned this way ever since $1864 .{ }^{66}$ In this regard, Steyger also quotes the following words of a British Member of Parliament from the mid-1980s:

The Europeans have gone too far. They are now threatening the British sausage. They want to standardise it, by which they mean they'll force the British people to eat salami and bratwurst and other garlic-ridden greasy foods that are TOTALLY ALIEN to the British way of life. ${ }^{67}$

\footnotetext{
62 Thoburn v Sunderland City Council, Hunt v Hackney London Borough Council, Harman and Another v Cornwall County Council, Collins v Sutton London Borough Council [2002] EWHC 195 (Admin), [2002] 3 WLR 247.

63 See B Dunaway, 'A Better Standard?' (LewRockwell.com 2001) <http://www.lewrockwell.com/orig/dunaway2.html> accessed 15 April 2011.

64 See also $R v$ Secretary of State for Transport, Exp Factortame Ltd (No 2) (C-213/89) [1991] 1 AC 603, 658-659, where Lord Bridge Harwich emphasised the danger of a takeover of the national parliament's sovereignty by EU institutions assisted by the national courts enforcing EU law.

65 “'Metric martyrs"' lose court battle' BBC News (18 February 2002) <http://news.bbc. co.uk/2/hi/uk_news/england/1826503.stm> accessed 9 September 2011.

66 See A Judd, 'What MPs didn't Tell you about the Common Market' (Metric Martyrs Defence Fund 2005) <http://www.metricmartyrs.sageweb.co.uk/heath.htm> accessed 15 September 2006.
}

67 Steyger (n 18) 1. 


\section{The internal market in the light of the subsidiarity principle}

Although the internal market is beneficial to all Member States, its scope and effect upon other important national values, such as autonomy, tradition and culture are contentious. A certain degree of uniformity and the removal of hindrances are necessary for the EU economy, but still it is an undeniable fact that the Member States are diverse and thus uniform rules are not always appropriate from the democratic legitimacy point of view. For this reason, the choice between various institutional alternatives in the EU market cannot always be based on economic effectiveness alone. One must also consider other values that are more easily achieved when EU law recognises certain Member State competences in the field of market law.

The disparity between uniform market rules in the EU and demands for democratic legitimacy was given its legal manifestation by the Treaty of Maastricht, which expressed Member States' reservations about enhanced integration through the principle of subsidiarity. This principle presents the foundation upon which Member States may advocate decentralism and the preservation of traditional rules and thereby keep certain competences at the national level. This principle requires decisions to be adopted as close to citizens as possible, and that in fields that are not within its exclusive competence, the EU acts only when Member States cannot achieve satisfactory results. ${ }^{68}$ As such, the principle of subsidiarity is an important component of the democratic legitimacy that is expected from modern legal systems. The principle of subsidiarity imposes rules on the division of competences between Member States and EU institutions. According to this principle, the latter may only have the competence to act in those areas that cannot be solved effectively at lower levels of government. It is thus the most reassuring principle for the democratic legitimacy of the decision-making processes in the EU and thereby for the diversity of adopted rules. ${ }^{69}$ As Pernice points out, subsidiarity in Europe is designed 'to preserve, to the [greatest] possible extent, the cultural and political identities of the Member States that have decided not to merge into a great European "melting pot" governed by a centralist bureaucracy. ${ }^{70}$

\footnotetext{
68 Article 5(3) TEU states: 'Under the principle of subsidiarity, in areas which do not fall within its exclusive competence, the Union shall act only if and in so far as the objectives of the proposed action cannot be sufficiently achieved by the Member States, either at central level or at regional and local level, but can rather, by reason of the scale or effects of the proposed action, be better achieved at Union level.'

${ }^{69} \mathrm{~J}$ Scott and DM Trubek, 'Mind the Gap: Law and New Approaches to Governance in the European Union' (2002) 8 European Law Journal 1, 8.

70 See GL Neuman, 'Subsidiarity, Harmonization and Their Values: Convergence and Divergence in Europe and the United States' (1996) 2 Columbia Journal of European Law 573 n 13.
} 
However, the problem with this principle is that it was included in the Treaties as a political compromise to assure acceptance of the Treaty of Maastricht by the Member States and not actually to limit the competences of EU institutions. This is evident from the Commission's opinion of 1992 that the four fundamental freedoms of the internal market fall among the exclusive competences of the EU. ${ }^{71}$ Such a classification would release the Commission from having to justify an enormous share of its legislative competences on the basis of the principle of subsidiarity. In this regard, Toth advocated that the EU has exclusive competence in all the areas in which it is competent to act, including the internal market, and that in reality there cannot be a concept called shared competence. ${ }^{72}$ Accordingly, in 1995 in Bosman, ${ }^{73}$ the Court concluded that fundamental freedoms, such as the free movement of people, are not subject to the subsidiarity review. ${ }^{74}$

Nevertheless, after expressing doubts about the real importance of subsidiarity, legal theory gradually began to emphasise that subsidiarity should be taken more seriously, ${ }^{75}$ and thus it has lately transformed from a political into a legal principle that should ensure a more democratically legitimate EU legal system. In this regard, the Lisbon Treaty also classified the internal market as an area of shared competences, thereby formally recognising the importance of subsidiarity in the field of the internal market. This demonstrates a mental leap towards a wholly more democratic EU system. ${ }^{76}$ Accordingly, the recognition that the internal market is not within the exclusive competence of the EU, and that the

\footnotetext{
${ }^{71}$ Commission, 'The Principle of Subsidiarity', Commission Communication to the Council and the European Parliament, SEC (92) 1990 final, 27 October 1992. See also G de Burca, 'Reappraising Subsidiarity's Significance after Amsterdam' (1999) Harvard Jean Monnet Working Paper 7/99, 20.

72 AG Toth, 'A Legal Analysis of Subsidiarity' in D O'Keeffe and P Twomey (eds), Legal Issues of the Maastricht Treaty (Chancery Law Publishing 1994).

73 Case C-415/93 Union Royale Belge des Sociétés de Football Association ASBL v Bosman [1995] ECR I-4921.

74 The Court thereby rejected the argument of the German government that the principle of subsidiarity requires such an interpretation of Article $45 \mathrm{TFEU}$ that it does not bind private organisations, such as UEFA.

75 Especially after the Court expressed its resistance to the principle of subsidiarity (eg Case C-84/94 United Kingdom v Council [1996] ECR I-5755). See G Bermann, 'Taking Subsidiarity Seriously: Federalism in the European Community and the United States' (1994) 94 Columbia Law Review 332; N Bernard, 'Discrimination and Free Movement in EC Law' (1996) 45 ICLO 82; T Schilling, 'A New Dimension of Subsidiarity: Subsidiarity as a Rule and a Principle', Yearbook of European Law (1994) 203.

76 This is further demonstrated by the rephrased national identity guarantee under Article 4(2) TEU. For a discussion on whether this guarantee has any consequences in internal market case law, see S Rodin, 'National Identity and Market Freedoms after The Treaty of Lisbon' (2011) Social Science Research Network <http://ssrn.com/abstract=2005691> accessed 27 September 2012.
} 
EU and the Member States share competence in this field does not present by itself a threat to market functioning, as many neoliberals believe. The balance of power is certainly in favour of the EU, which may limit states' competence in this field through the principle of the supremacy of EU law. However, this does not mean that the internal market cannot be more the result of a stakeholder process, which would expressly recognise the active role of the Member States in market regulation, thereby recognising the proper role of subsidiarity.

The main consequence of subsidiarity in terms of the choice between institutional alternatives in the field of the internal market is in its requirement to limit centralism and recognise Member States' primary role in market regulation, but under the condition that they do not discriminate against people, goods and services from other Member States. Recognising the important role of subsidiarity in EU law leads to the view that the internal market does not require a market of completely uniform rules. The Court must shape public law doctrines in such a way that the centre of democratic legitimacy in the EU stays with the Member States. This is especially true for interpretation of EU competences from the TFEU. The US Supreme Court held in Chevron ${ }^{77}$ that American courts must (if Congress has not expressly regulated the issue concerned) adopt a permissible interpretation of the delegation of competence from democratically more legitimate and responsible levels of government to less legitimate ones. ${ }^{78}$ This permissible interpretation also requires that goals of an ideal market be substituted by the goal of a workable market. When considering other values besides economic liberalisation, the internal market may not be considered as a perfect market. As former judge Jann once said: 'Discussions must concentrate on the common market that truly exists and not on the ideal market that has no failures. The latter simply does not exist. ${ }^{79}$ Thus, the difference between a pure, ideal internal market and a workable internal market is not insignificant; recognition of differences between national markets makes it possible to take proper account of differences which the EU internal market should recognise. Examples of how to give priority to the concept of a workable market over that of an ideal market can be found in US market law. In many aspects, the US Supreme Court has been less strict in supporting the unification of market law than the EU Court, which is evident from

\footnotetext{
77 Chevron USA, Inc v Natural Resources Defense Council Inc, 467 U S 837 (1984).

78 See also more recent case law where the US Supreme Court acknowledges broader state competences in the market field: United Haulers Assn Inc v Oneida-Herkimer Solid Waste Mgmt Auth, 550 US 330 (2007); Department of Revenue of Kentucky v Davis, 553 US 328 (2008).

79 K Tomasz, 'Trybunal Sprawiedliwosci i integracja: Rozmowa z sedzią Trybunału Peterem Jannem’ (2002) 2 Radca Prawny 95, 100.
} 
the fact that the Supreme Court dismissed the premise that 'every action by a State that has the effect of reducing in some manner the flow of goods in interstate commerce is potentially an impermissible burden', ${ }^{80}$ which in fact is the well-known Dassonville formula under EU law. ${ }^{81}$

In addition, application of the de minimis principle in the field of economic freedoms should be considered as a potential instrument for enhancing the democratic legitimacy of EU internal market rules. Perišin makes an important point in this respect by saying that

times have changed since Dassonville and Cassis ... and it is nowadays not necessary for Article (34) to be so broad as to cover all obstacles to trade, and the Court's review over measures which are only remotely connected to the internal market would be unnecessarily burdensome on national regulatory autonomy, and would thus endanger the EU's legitimacy. ${ }^{82}$

The de minimis rule is thus a useful concept to reduce centralisation in the field of the internal market and to balance free trade and national autonomy interests. Nevertheless, its application in this field is by no means without problems.

Yet, there are more recent signs that EU law is evolving towards putting more emphasis on national identity. Advocate General Maduro found in Michaniki in 2008 that 'the European Union is obliged to respect the constitutional identity of the Member States'. ${ }^{3}$ Article 4(2) of the Treaty on European Union, as amended by the Treaty of Lisbon, is very clear about this by stipulating that the Union respect the "national identities [of Member States], inherent in their fundamental structures, political and constitutional'. The Court also expressly recognised that the preservation of national identity is a legitimate aim respected by the Community legal order'. ${ }^{84}$ However, it has often ruled that the restriction in the case in point was disproportionate as the interest pleaded could be effectively safeguarded by other means. However, in more recent rulings, adopted after the entry into force of the Treaty of Lisbon, the Court is more sensitive towards national identity, even when it is in opposi-

\footnotetext{
80 Hughes $v$ Alexandria Scrap Corp, 426 US 794 (1976).

81 See T Stein and E Sandalow, Courts and Free Markets, Perspectives from the United States and Europe, Vol 1 (Clarendon Press 1982) 25; C Barnard, 'Restricting Restrictions: Lessons for the EU from the US?'(2009) $68 \mathrm{CLJ}$ 575-606.

82 T Perišin, Free Movement of Goods and Limits of Regulatory Autonomy in the EU and WTO (Asser Press 2008) 39.

83 Case C-213/07 Michaniki AE $v$ Ethniko Symvoulio Radiotileorasis and Ypourgos Epikrateias [2008] ECR I-9999, Opinion of AG Maduro, para 31.

84 See Case C-473/93 Commission v Luxembourg [1996] ECR I-3207, para 35.
} 
tion to free movement values. ${ }^{85}$ An example of this development is SaynWittgenstein, ${ }^{86}$ which concerned a woman with Austrian citizenship who was adopted by a German and who was not permitted to use the title of Fürstin in Austria. The reason for this was that the Verfassungsgerichtshof (Austrian Constitutional Court) held in 2003 that the Abolition of the Nobility Act of 1919, which has constitutional status and implements the principle of equal treatment, precludes an Austrian citizen from acquiring a surname which includes a noble title by means of adoption by a German citizen who is permitted to bear that title as a constituent element of his name. As Ms Sayn was an estate agent, she claimed that the impossibility of registering her civil status would impair her freedom to provide services. The Court noted that the European Union is to respect the national identities of its Member States, which includes the status of a State as a Republic. The Court therefore accepted that in the context of Austrian constitutional history, the Abolition of the Nobility Act may be regarded as a public policy justification and accordingly, when balanced against the right of free movement of people, recognised under European Union law. ${ }^{87}$ The Court is thus slowly becoming more willing to preserve national autonomy and tradition. ${ }^{88}$

\section{Conclusion}

The paper highlights that the rules that mirror certain ways of life in individual Member States face considerable challenges under EU law. The equivocal definitions and goals of the Treaty have enabled the EU to influence unforeseen areas. Consequently, the four freedoms have had a significant impact on people's way of life. These provisions of the TFEU have, together with the EU Court's case law, led to a considerable limitation of autonomy and to the removal or adjustment of numerous national traditions. The positive integration of EU legislation has had similar restrictive effects on Member States' sovereignty when regulating traderelated and other issues. The effect of the all-encompassing uniformity of legal rules and EU law upon people's way of life, and in certain areas intrusive interference in the values that are a source of national pride, conflict with the essence of democratic legitimacy and must become a factor of institutional analysis.

\footnotetext{
85 Rodin (n 76) 16.

86 Case C-208/09 Ilonka Sayn-Wittgenstein v Landeshauptmann von Wien [2010] ECR I13693.

87 Sayn-Wittgenstein (n 86) para 89.

88 See also Case C-391/09 Malgožata Runevič-Vardyn and Łukasz Pawet Wardyn v Vilniaus miesto savivaldybès administracija and Others [2011] OJ C194/04.
} 
The principle of subsidiarity can in this respect apply a brake on the erosion of national competences. Bermann defines the values of subsidiarity as 'self-determination and accountability, political liberty, flexibility, preservation of identities, diversity and respect for internal divisions of component states'. ${ }^{89}$ This principle confers upon Member States the role of primary market regulator. However, this does not mean that supranational institutions are excluded from acting in this field. As such, the principle reflects the multi-level governance system, which must also be recognised in the field of the internal market. The principle of subsidiarity is foremost a concept to assure high quality and democratically legitimate EU market law. It requires the determination of whether Member States may effectively regulate certain matters and that the EU legislator ex ante weighs the proposed rules. Certainly, this may slow down the legislative procedure and require greater justification of Commission proposals. However, at the same time, it leads to better and more thoroughly considered legislation that more consistently considers national culture and tradition. As the present state of EU enthusiasm shows, the melting pot is not going to be a preferential standpoint of the majority of Europeans for decades to come. Even the most centralist EU institutions are aware of this fact. In his speech in Sofia in 2007, Commissioner McCreevy emphasised:

we need to accept that the nature of the game has changed. ... The Single Market must become more decentralised .... We need to improve the ownership in the Member States. And we must strengthen cooperation between the national and EU level'. ${ }^{90}$

Today this is even more vital, considering that the economic crisis has strengthened Euroscepticism in most EU Member States, which is evident from increasing nationalism, lack of cross-border solidarity and negative attitudes towards imported goods and foreign workers and service providers. Despite the fact that decentralisation of the EU internal market is contrary to the basic principles of EU legislation and the case law of the past two decades and seems, from the legal point of view, rather ambiguous, it is the result of a multi-dimensional division in the EU and its increasing diversity.

Furthermore, in a 2011 Green Paper, the Commission stated that regional and local markets are an essential meeting place for producers and consumers, as they provide the latter with access to a wide variety

\footnotetext{
89 Bermann (n 75) 343.

90 C McCreevy, 'The Future of the Single Market' (Sofia University, Sofia, 14 May 2007) $<$ http://europa.eu/rapid/pressReleasesAction.do?reference=SPEECH/07/308\& format=H TML\&aged=1\&language=EN\&guiLanguage=en $>$ accessed 22 July 2011.
} 
of products rooted in their traditions and ways of life. ${ }^{91}$ The previously mentioned Judge Jann held:

today the Court is aware that the judges must establish a balance for a successful market. [On] one hand, we must do all we can to remove barriers, at the same time, however, we must be aware that there are national interests that must be protected, even when this protection means keeping certain barriers in the functioning of the ideal internal market. ${ }^{92}$

Nevertheless, given the established market law of the EU it is difficult to imagine that any of these institutions would expressly clear a Member State measure such as introducing traditional national breakfast to schools where only food of local origin would be served. In the light of the famous Dassonville formula, such a measure would clearly be direct discrimination that cannot be justified on the basis of Article 36 TFEU. It is thus hard to see how national tradition and culture can comfortably exist within the internal market principles as currently interpreted. In contrast to this, it should be more clearly reflected in the law that the market is diverse and complex. In the light of this, national culture and tradition should effectively be integrated in the system of derogations to internal market principles and be treated as per se values. This would considerably improve EU market legitimacy, which will be essential for strengthening the EU project post-crisis.

91 Commission, 'Green Paper on promotion measures and information provision for agricultural products: a reinforced value-added European strategy for promoting the tastes of Europe' COM (2011) 436 final 4-5.

92 Tomasz (n 79) 100. 